\title{
Editorial
}

\section{Exploring Culturally Diverse Leadership Styles: A Mindset and Multicultural Journey}

\author{
Joseph E.Trimble, PhD ${ }^{*}$; Jean Lau Chin, EdD,ABPP2
}

'Department of Psychology, Western Washington University, Bellingham, WA 98225, USA

${ }^{2}$ Gordon F. Derner School of Psychology, Adelphi University, Garden City, NY I I 530, USA

\section{"Corresponding author}

Joseph E.Trimble, PhD

Distinguished University Professor, Professor of Psychologyr, Department of Psychology, Western Washington University, Bellingham, WA 98225, USA;

E-mail: trimble@wwu.edu

\section{Article Information}

Received: August $4^{\text {th }}$, 2018; Revised: January $8^{\text {th }}, 2019$; Accepted: January 19th 2019 ; Published: January $22^{\text {nd }}, 2019$

Cite this article

Trimble JE, Chin JL. Exploring culturally diverse leadership styles:A mindset and multicultural journey. Soc Behav Res Pract Open J. 20I9; 4(I): el-e2. doi: $10.17 \mid 40 /$ SBRPOJ-4-e05

$\mathrm{W}$ th few exceptions, the current theories and research on leadership neglect the value of cultural diversity when considering different leadership styles. Rather, leadership theories continue to reflect a white, North American, heterosexual, male bias and omit dimensions of diversity in researching how leadership is exercised and the values effective leaders promote. Yet, there's little question the growing population diversity in our complex and uncertain world requires a deep understanding of how effective leadership is exercised and the role leaders will play in managing the changes ahead. ${ }^{1-5}$

To prepare ourselves, our communities and our institutions to live and work in this global world of the future require a hard look at existing leadership models that ignore ethnic and racial diversity. These entrenched models are overwhelmingly ethnocentric and gender-biased. They draw on narrow, cultural-specific knowledge and practices that simply are not relevant for a diverse and global population, nor applicable in varying contexts and changing social environments. By failing to explore the deep core of culturally unique leadership styles among non-white populations, researchers too often have overlooked leadership styles that have endured for centuries through sheer effectiveness in leading and governing their people. ${ }^{4-6}$

How, then, are diverse and contextually relevant leadership styles to gain the respect and action they deserve? It is not simply about the representation of diverse leaders in the ranks of leadership, nor about affirmative action. Rather, it requires paradigm shifts in our theories of leadership that examine and incorporate the ways diversity shapes our understanding of leadership and its effects.

To be effective, our future leaders must be responsive to change, prepared to lead a diverse workforce, and comfortable with multicultural communities that may differ from their own. This requires that leaders and leadership models be inclusive and sensitive to difference, which in turn requires an openness to diverse leadership styles. Yet when many women and members of non-white racial and ethnic groups become part of the power elite in organizational leadership roles, they often become more like those already in power. ${ }^{7}$ This raises the question of how our institutions and corporate structures constrain leaders to mirror the way those in leadership roles lead. ${ }^{8}$

To avoid the mirroring effect, attention to a more culturally sensitive perspective is highly important. A transformative multicultural style might reframe "empathy" into "inclusive relational empathy" to emphasize a more relationship-centered perspective, for example. A transformative style places emphasis on connecting the follower's sense of identity and self to the mission and collective identity of the group or organization. ${ }^{6}$

Developing and practicing a culturally inclusive mindset is a dynamic and complex process - a multicultural journey, in effect. An aspiring culturally sensitive leader must focus on developing the appropriate skills, understanding, appreciation, willingness, and ability to lead culturally different followers; the most salient of these is willingness, for without a conscious intent and desire the achievement and realization of cultural competence is not likely to occur. ${ }^{4,5}$

Amidst rapid technological change, emerging global concerns, changing population demographics, and new social contexts, a diverse leadership style means being competent to:

- Understand how different world-views and lived experiences influence the exercise of leadership and leadership styles;

- Be inclusive of social justice, ethical, and value-based di- 
mensions of leadership that are not typically included in mainstream dialogue about leadership;

- Recognize how perceptions and expectations of leaders associated with dimensions of identity (e.g., gender, race, ethnicity) may result in biases that shape leader behaviors and influence appraisals of leader effectiveness for those who do not fit the prototype of a "typical leader"; and

- Reflect the importance of context in shaping leadership, including the leader's respect for culturally diverse leaders and members. ${ }^{4,5,9}$

Studies now emerging point to the importance of social identities and lived experiences of leaders in their interaction with diverse followers in social and organizational contexts. Leaders with social identities reflective of marginalized or minority groups are very likely to face a different experience in their positions than the typical white male leader, suggesting leaders with these challenges must develop self-monitoring skills and use race and other dimensions of diversity, such as sensitivity to exclusion, as a positive resource rather than a deficit or weakness. ${ }^{7,8}$

Becoming culturally competent and sensitive does not imply that one discard the many contributions of past and present social and behavioral scientists and scholars. The challenge is to recognize that we cannot fully understand the human condition without viewing it from a cross-cultural perspective. What has been learned about the human condition in the past can be reframed and tested with a new set of approaches and procedures in cultural contexts not previously considered. We must challenge our existing beliefs about effective leadership, ask new questions, and offer new paradigms to guide how we lead in today's world. By so doing, we will find a rich vein of specific thought ways and lifeways of various ethnocultural groups with extraordinary value for leadership as a whole.

\section{ACKNOWLEDGEMENT}

We are deeply indebted to Molly E. Trimble, who provided skillfully worded editorial comments and suggestions through draft versions of this editorial. We are extremely grateful for her time, effort, and thoughtful assistance.

\section{CONFLICTS OF INTEREST}

The authors declare that they have no conflicts of interest.

\section{REFERENCES}

1. Turnbull S, Case P, Edwards G, Schedlitzki D, Simpson P. (Eds) Worldly Leadership: Alternative Wisdoms for a Complex World. London, UK: Palgrave Macmillan. 2012.

2. Chin JL. Special Issue: Diversity and leadership. American Psychologist. 2010; 65(3): 150-226.

3. Chin JL, Lott B, Rice J. Sanchez-Hucles J. (Eds). Women and Leadership: Transforming Visions and Diverse Voices. Hoboken, New Jersey, USA: Wiley-Blackwell. 2007.

4. Chin JL, Trimble JE. Diversity and Leadership. Los Angeles, California, USA: SAGE Publications. 2014.

5. Chin JL, Trimble JE, Garcia, JE (Eds.). The Culturally Diverse Leader: New Dimensions, Opportunities and Challenges for Business and Society. Bingley, United Kingdom: Emerald Group Publishing Limited. 2017.

6. Bordas J. Salsa, Soul and Spirit: Leadership for a Multicultural Age. San Francisco, California, USA: Berrett-Koehler. 2007.

7. Zweigenhaft RL, Domhoff N. Diversity in the Power Elite: How it Happened, Why it Matters. New York, USA: Rowman \& Littlefield. 2006.

8. Haslam SA, Reicher SD, Platow MJ. The New Psychology of Leadership: Identity, Influence, and Power. New York, USA: Routledge. 2010.

9. Chin JL. Diversity in Mind and in Action. Santa Barbara, California: Praeger. 2009. 